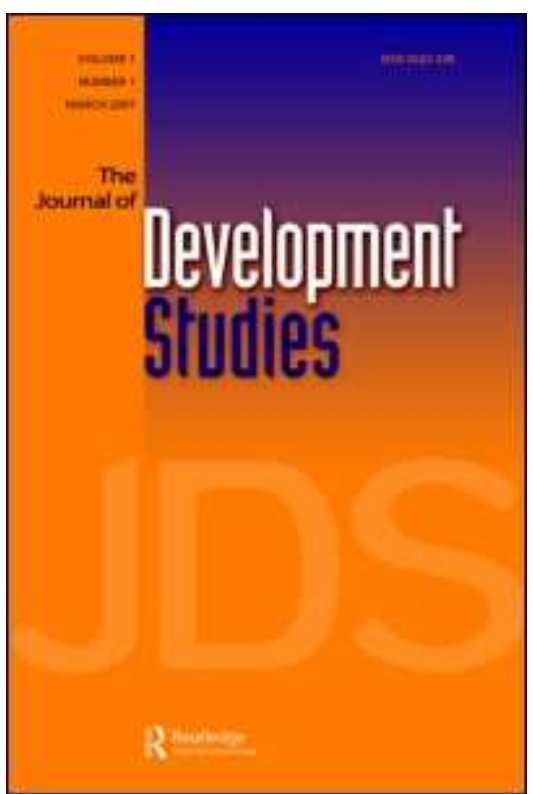

\title{
Do remittances lead to a public moral hazard in developing countries? An empirical investigation
}

\begin{tabular}{|r|l|}
\hline Journal: & Journal of Development Studies \\
\hline Manuscript ID: & FJDS-2010-Aug-0005.R3 \\
\hline Manuscript Type: & Original Manuscripts \\
\hline Keywords: & $\begin{array}{l}\text { Economic development < Economics, Governance < Government, } \\
\text { State Policy, \& Ideologies, Health < Health, Education < Education, } \\
\text { Migration < Employment and Law }\end{array}$ \\
\hline \multicolumn{2}{|l}{} \\
\hline
\end{tabular}

\section{SCHOLARONE \\ Manuscripts}




\title{
Do Remittances Lead to a Public Moral Hazard in Developing Countries?
}

\author{
An Empirical Investigation
}

\begin{abstract}
This paper tests the hypothesis that in a context of 'bad governance', remittance inflows strongly reduce public spending on education and health in receiving countries; a phenomenon called the 'public moral hazard problem'. Using a large sample of 86 developing countries over the period 1996-2007, and after factoring in the endogeneity of remittances, the results suggest a negative impact of remittances on public spending on education and health, when governance is bad in remittancedependent economies.
\end{abstract}

Key words: remittances, governance, public spending, developing countries

JEL codes: F24, H41, E62, O23 


\section{Introduction}

International migration constitutes one of the biggest aspects of the current economic globalization. One of the main consequences of migration is remittances, in others words the money sent back to home by migrants. Remittances constitute a significant amount of the resources received by developing countries, and some scholars argue that remittances are an external and stable source of funding for development (Ratha, 2005). To put some numbers in perspective, the level of remittances attained 338 billion US dollars in 2008. And despite the recent worldwide crisis, remittances have shown a stronger comparative resilience than the other types of financial flows received by developing countries. Moreover, for a number of countries, remittances represent the most important source of external funding, exceeding the levels of foreign aid or foreign direct investment (Ratha, 2009). The level of remittances exceeds that of aid in the whole developing world and they represent the second largest external source of funding after foreign direct investment.

The literature on the contribution of remittances to development can be split into two broad camps: on one side, the club of optimists and on the other side, the club of sceptics. Taking an optimistic view, remittances contribute to the development of recipient countries by relieving households' financial constraints, and by protecting them against several types of shocks. Overall, remittances enhance economic growth, reduce poverty and help cope with shocks (Adams, 2005; Yang, 2008; Gupta et al., 2009; Giuliano et al., 2009; Bugamelli and Paternò, 2009; Chami et al., 2009; Ebeke, 2010a, Combes and Ebeke, 2011).

For the sceptics, remittances are simultaneously a gift and a curse. By leading to an appreciation of the real exchange rate, or by reducing labor force participation in recipient country households, remittances do not contribute to economic development in the long run (Amuedo-Dorantes and Pozo, 2004; Chami et al., 2003; Chami et al., 2005). The main motivation of these "sceptical" papers is to show that remittances are not a panacea, and that sometimes they may harm sustainable economic growth. For example, Catrinescu et al. (2009) seek to explain the ambiguity among studies on the impact of remittances on economic growth by relating the effect of remittances to the quality of domestic institutions in recipient countries. Specifically, they show that remittances are more likely to contribute to longer-term growth when the remittance receiving countries' political and economic policies and 
institutions create the incentives for financial and business investment and savings from remittances.

Amuedo-Dorantes and Pozo (2004), using a sample of Caribbean and Latin American countries, showed that a rise in remittances is associated with an appreciation of the real exchange rate. Chami et al. (2003) and Chami et al. (2005) pointed out that remittances create a moral hazard problem between the migrant and the recipient household when the latter has the incentive to reduce its labor force participation while increasing its leisure time.

A recent part of this literature explores the negative side-effects of remittances by questioning the contribution of these flows to economic policy. Shabbaz et al. (2008) investigate the relationship between the surge in remittances and government spending in Pakistan. They tested the hypothesis that remittances reduce the size of government by insulating both government and domestic population from the vagaries of the global economy. This idea has been developed and tested by Kapur and Singer (2006), and Ebeke (2011), for a large sample of developing countries.

Abdih et al. (2008) using a large sample of developing countries, and after factoring in the endogeneity of remittances, have shown that remittances reduce institutional quality in recipient countries. This arises because the access to remittance income makes government corruption less costly for domestic households to bear; consequently corruption is likely to increase.

Grabel (2009) pointed out that remittances may create a 'public moral hazard' on the part of developing country governments. That is, by partially resolving bottlenecks, remittances may actually encourage states in the developing world to ignore their traditional responsibilities because they assume that remittances will fill various voids.

Chami and Fullenkamp (2009) propose a more severe analysis of the effects of remittances in recipient countries. They argue that if conditions are bad at home, families send more members abroad and use remittance income to compensate for the lack of government services. Therefore, they lose interest in pressuring the government to deliver better services, and the quality of government declines because the government does not feel compelled to provide services as it realizes that households can fend for themselves. 
This paper extends the previous analyses on the relationship between remittances and government behavior in recipient countries. I investigate what happens on the part of the public sector when remittances flow into countries characterized by bad governance. I test the hypothesis of the existence of a 'public moral hazard problem' by examining the effects of remittances inflows on the levels of public social spending when the government is not accountable. The hypothesis is validated when remittance inflows reduce government spending on social sectors. I propose the hypothesis that this behavior is more likely to be observed in countries when the public sector is not accountable.

This can be explained by at least three arguments. Firstly, remittances constitute a form of private subsidy, and therefore bad governments can easily reduce public subsidies on these sectors. Secondly, access to remittances income makes a reduction of government subsidies less costly for domestic households to bear, a situation that might be exploited by rogue governments to divert resources. Thirdly, access to remittances income might reduce the incentive for recipients' households to exert accountability on governments. It is then plausible that individuals do not exert pressure on government for change simply because they can resort to remittances to solve their problems. Therefore, it is as if people renounce pressure for change more easily if they can receive an external assistance like remittances. This is also a form of moral hazard problem on the part of households which translates into a public moral hazard problem.

A large sample of developing countries is retained in order to test the impact of remittances on social public subsidies. The period of analysis is 1996-2007 and the unit of observation is the country. This period is retained for a number of reasons. As in Abdih et al. (2008), I use as my main dimensions of governance and accountability, all the indicators provided by Kaufmann et al. (2009) in the World Bank Governance Indicators dataset.

I take advantage of the panel data structure of the dataset to estimate the effect of remittances on public social spending. Because remittances are plausibly endogenous and because public spending on social sectors is strongly autoregressive, the system-GMM estimator is useful to permit the reduction of the bias associated with the estimation of the autoregressive models as well as to instrument remittances with their lagged values. For robustness checks, I also present the results obtained from an augmented system-GMM estimator which includes an 
external instrument for remittances and which allows a common factor representation, and results from the difference-GMM estimator.

The results of the econometric analyses do not reject the hypothesis of this paper. It appears that remittances reduce public spending on education and health in countries 'badly' governed.

The remainder of the paper is as follows: Section 2 presents the econometric model of the relationship between remittances, governance and public spending, Section 3 discusses the results of estimations and provides empirical regularities, Section 4 checks the robustness of these results and I conclude with policy implications in Section 5.

\section{Empirical Design}

\section{Econometric specification}

The model specified is designed to measure the impact of remittances on the level of public spending on education and health among different levels of governance. For the choice of control variables, I take advantage of previous empirical models of the determinants of public spending on education and health in developing countries. These models are augmented with linear and multiplicative terms of remittances, and remittances crossed with the governance variables. Formally, the specification retained is the following:

$$
S_{i t}=S(R, R * G, G, X)
$$

where $S$ is either the overall measure of social spending, public spending on education or public spending on health in percent of GDP. $R$ is remittances as a percentage of GDP, and $G$ is the index of governance quality. All the variables are expressed in the natural logarithmic form except the governance variables.

By controlling additively for the levels of remittances and governance quality, I ensure that the interaction term does not proxy for remittances or the level of institutional quality. This is an important point because remittances may have a direct effect on the quality of domestic institutions as has been shown by Abdih et al. (2008). The impact that I identify here is however the influence of remittances on the level of public pro-poor expenditures in countries with governance problems. 
The model estimated with a yearly panel data structure is a dynamic panel data model with the following form:

$$
S_{i, t}=\rho S_{i, t-1}+X_{i, t}^{\prime} \beta+\theta_{1} R_{i, t}+\theta_{2} R_{i, t} * G_{i, t}+\theta_{3} G_{i, t}+u_{i}+\varepsilon_{i, t}
$$

with $u_{i}$ the country fixed effects.

A dynamic specification is used given the strong inertia characterizing government spending, which is often renewed every year in budgets. The hypotheses tested are that remittances $(R)$ are negatively associated with public spending on education and health at high levels of bad governance (existence of a public moral hazard effect due to remittances). Formally, this suggests that $\theta_{2}<0$ and $\theta_{3}<0.1$

Remittances are suspected of endogeneity because of omitted variables bias and reverse causality. Indeed, there exist some variables which might affect both remittances and public spending. For example, external shocks could influence remittances as well as the level of public social spending. Another omitted variable is the level of emigration, which is directly linked to remittances, and also affects the propensity of government to subside social sectors. Moreover, emigration of individuals decreases the domestic tax base, government tax revenue and its capacity to supply public services. ${ }^{2}$ Finally, endogeneity of remittances may also arise because of reverse causality. If the level of public spending on education or health is too low to permit households to use services, remittances can be sent to increase the access of recipient households to health care services or education (e.g. in the private sector). Moreover, a low level of public spending, which results in a low quality of public services, could encourage households to use remittances in the private sector, where the quality of similar services (e.g. schools, private clinics) is expected to be higher (Drabo and Ebeke, 2010). Altogether, it can be expected that the coefficients associated with remittances in OLS estimations will be downward biased.

Hence an econometric strategy based on instrumental variables must be implemented. I therefore resort to dynamic panel data estimators that allow the instrumentation of the explanatory variables suspected of endogeneity. Two commonly used estimators are retained: the difference-GMM estimator (Arellano and Bond, 1991) and the system-GMM estimator (Arellano and Bover, 1995; Blundell and Bond, 1998). ${ }^{3}$ In the difference-GMM estimator, the model (2) is taken in first differences (to remove country fixed effects), and the first 
differentiated variables are instrumented by the lagged values of the variables in level. However, it has been recognized that the lagged values of variables in level are sometimes poor instruments for variables in first differences. The system-GMM estimator therefore increases the moment conditions in order to improve the efficiency. The equation in levels and the equation in first differences are combined in a system, then estimated with an extended GMM estimator system which allows for the use of lagged differences and lagged levels of the explanatory variables as instruments.

The GMM estimators designed for dynamic panel data are suitable to deal with endogeneity problems arising from simultaneity bias but also from reverse causality. Regarding the latter case, if low levels of public education and health expenditures increase the level of remittances sent to a country (because migrants may remit more to countries with low levels of public spending on education and public health), the naïve estimation techniques such as the OLS method give biased results. In contrast, the GMM estimators could reduce this reverse causality bias given that the lagged values of remittances used as the instruments for remittances are not affected by the contemporaneous levels of public spending. However, one limitation often recognized in the dynamic panel GMM techniques is that the lagged values of the endogenous variables are sometimes poor instruments for the variables in first differences. If this holds, correcting the reverse causality bias through the use of the lagged values of the explanatory variables as instruments is misleading. This is why in this paper, the standard GMM estimator techniques are augmented by adding an "external instrument" that is suggested by the recent empirical literature on the macroeconomic determinants of remittances. The income per capita in the migrant host countries is therefore retained as the "external source of variation" for remittance inflows (see Section IV for a detailed discussion justifying the choice of this instrument). The addition of this external instrument should go some way towards vitiating the potential "weak instruments", simultaneity and reverse causality problems, that often arise in the context of traditional GMM estimations.

\section{The variables}

Two models are estimated according to the dependent variable used. I begin in each case with the model of public education spending. The exercise is repeated afterwards for public health spending. ${ }^{4}$ 
Data on public health spending and public education spending are taken from a dataset compiled by the Fiscal Affairs Department of the IMF (FAD). ${ }^{5}$

Following the empirical literature on the determinants of public spending on education and health in developing countries (Gbesemete and Gerdtham, 1992; Feyzioglu et al., 1998; Baqir, 2002; Okunade, 2005; Stasavage, 2005; Fosu, 2007, 2008; Docquier et al., 2008), the set of control variables includes:

- GDP per capita in constant prices: this variable is included to control for the level of development among countries in the sample, but also to catch the elasticity of public spending with respect to income. Previous studies have found that public spending in social sectors is a normal good in developing countries (Okunade, 2005).

- Foreign aid: this variable catches the sensitivity of pro-poor government expenditure to external assistance from donors. This variable appeared to be positively related to government spending in previous studies (Gbesemete and Gerdtham, 1992; Gomanee et al., 2005; Fosu, 2007). Three variables of aid are used in this paper: aggregate aid, education aid and health aid, according to the dependent variable retained. Aggregate aid per capita series are drawn from the World Development Indicators while sectorial aid comes from the Country Reporting System (CRS) of the OECD. ${ }^{6}$ The main advantage of the CRS is to provide data on aid commitments with a high degree of disaggregation by purpose (sector). Its main disadvantage though, is that the data are only reliable for recent years (since 1995). For sectorial data on aid, I always use aid commitments to each sector for education and health. ${ }^{7}$ All series of aid are normalized by the country nominal GDP before taking them in logarithms.

- Debt service ratio: this variable is included to control for the effect of financial constraints at the government level on the amount of pro-poor (social) spending. As seen in previous works (Fosu, 2007, 2008), I expect a negative impact of this variable.

- Young population (age <14): this variable catches the demand for public subsidies in the education sector. I also control for this variable to drain off the possible impact of remittances on the demand for schooling. This is important to ensure that the effect of remittances on government spending is not driven by the positive correlation between remittances and the demand for schooling, but only by the supply effects arising from public sector behavior. 
- Total population growth rate: this variable measures the annual growth rate of the population in each country and would be positively correlated with public health spending. I also control for this variable to ensure that the effect of remittances is primarily due to supply effects emanating from the public health sector, rather than a demand effect for health services fueled by the positive correlation between remittances and fertility. ${ }^{8}$

- Inflation rate: I control for the inflation rate (the growth rate of the GDP deflator index) to assess the impact of overall macroeconomic instability on the composition of public social spending. I therefore expect the coefficient of this variable to be negative.

- Urbanization rate: this variable is introduced to capture the public preference in the geographical allocation of public funds for education and health to rural or urban areas.

- Remittances: data on remittances are drawn from the IMF Balance of Payments Yearbooks. The remittance variable is defined as current private transfers from migrant workers, who are residents of the host country, to recipients in their country of origin. I do not include the other components, such as compensation of employees or migrant transfers, which do not exactly represent remittances as a flow and as private decisions. Data are expressed in percentage of GDP before transforming into logarithm.

- Governance: This variable captures the inability of the government to implement policies for sustainable development. ${ }^{9}$

Following Abdih et al. (2008), I use the World Bank Governance Indicators dataset since this dataset has provided measures of governance for a large number of countries since $1996 .{ }^{10}$ The Worldwide Governance Indicators (WGI) project has reported aggregate and individual governance indicators for 212 countries and territories since 1996. Six dimensions of governance are reported: voice and accountability, political stability and absence of violence, government effectiveness, regulatory quality, rule of law, control of corruption.

More recently, the six indicators were defined as:

- Voice and Accountability - measuring the extent to which a country's citizens are able to participate in selecting their government; as well as freedom of expression, freedom of association, and a free media. 
- Political stability and Absence of Violence - measuring perceptions of the likelihood that the government will be destabilized or overthrown by unconstitutional or violent means, including political violence or terrorism.

- Government effectiveness - measuring the quality of public services; the quality of the civil service and the degree of its independence from political pressures; the quality of policy formulation and implementation, and the credibility of the government's commitment to such policies.

- Regulatory quality - measuring the ability of the government to formulate and implement sound policies and regulations that permit and promote private sector development.

- Rule of law - measuring the extent to which Law Enforcement agents have confidence in and abide by the rules of society, and in particular the quality of contract enforcement, the police and courts, as well as the likelihood of crime and violence.

- Control of corruption - measuring the extent to which public power is exercised for private gain (including both petty and grand forms of corruption), as well as "capture" of the state by elites and private interests.

It should be noted that these governance indicators are all based on data from expert assessments, polls of experts and surveys of government officials and businesses, and therefore capture perceptions of the government process rather than any formal aspects of the actual government structure in any given country. This creates the important problem that perceptions are shaped not just by the government environment, but also by many other aspects of the socio-economic environment, thereby creating its own set of endogeneity and reverse causality issues. There is a large literature critical of the World Governance Dataset (Arndt and Oman, 2006; Kurtz and Shrank, 2006; Kurtz and Shrank, 2007). Kaufmann, Kraay and Mastruzzi have categorized some of these critiques as concerns about the comparability of the indicators across countries and across time; concerns about bias in expert polls or in particular sources; and concerns about the independence of the different data sources and the consequences for the aggregate indicators. (Kaufmann, Kraay and Mastruzzi, 2006). More recently, Thomas (2010) dismisses the Worldwide Governance Indicators (WGI) as an 'elaborate and unsupported hypothesis' because of the failure to demonstrate the 'construct 
validity' of these indicators. A short answer to Thomas (2010) is provided by Kaufmann et al. (2010). The authors cast doubts on the practical consequences of failure to meet the criteria of construct validity and therefore minimize this critique.

To build the indicators of governance used in the econometric estimations, I reverse all the original indicators of governance quality by the following formula:

$$
G_{i, t}=\frac{\max \left(x_{i, t}\right)-x_{i, t}}{\max \left(x_{i, t}\right)-\min \left(x_{i, t}\right)}
$$

where $x$ is each indicator of governance quality. $\operatorname{Min}(x)$ and $\max (x)$ represent the minimum and the maximum of each indicator, respectively. This transformation ensures that $\boldsymbol{G}$ will have a range between 0 and 1 . On this basis, $\boldsymbol{G}$ increases with the deterioration of the quality of governance. Moreover, equation (3) applied on each governance variable ensures the standardization of these variables into new indices which are therefore reasonably comparable. Given the fact that the indices are distributed over the same interval $[0,1]$, the coefficients of the interactive terms (remittances crossed with the governance variable) will allow direct comparison across the different equations. Descriptive statistics of all the variables and the list of countries in the sample are available in Table A1 and Table A2 of the Online Appendix. The sample used covers a large number of developing countries (86 countries).

Next, I turn to the estimations of the econometric models. The panel data is unbalanced given missing values for some countries.

\section{Results}

\section{Results for public education spending}

The results of the estimations of Model 2 specified for the case of public education are presented in Tables 1 and 2. Table 1 presents the results using the difference-GMM estimator, whereas Table 2 shows the results derived from the estimator of the system-GMM. In each table I present the diagnostic tests associated with these estimators, to be precise the test of autocorrelation of the residuals in first difference and the Hansen overidentification test. The estimations always pass the GMM specification tests. The residuals in first difference exhibit in each case a significant first order correlation, while the second order correlation is not 
significant. This validates the use of lagged values of explanatory variables as instruments. The Hansen overidentification tests do not reject the hypothesis that the instruments are not correlated with the residuals of the models.

In order to check the exogeneity of the instruments, I present the results of the difference-inHansen test which examines whether the instruments of the equation in level are exogenous in the system-GMM estimator (Roodman, 2009). Again, the results suggest that the instruments used in the system-GMM estimator are valid. Meanwhile, the number of lags of the endogenous variables has been limited to avoid the overfitting bias due to instrument proliferation (Roodman, 2009).

The public moral hazard problem induced by remittances would be validated if the interaction term of remittances crossed with the governance indicators is significantly negative once the additive terms of remittances and governance are controlled for. It appears that the interaction between remittance inflows and governance negatively affects the level of public spending on education. The results obtained by the difference-GMM method (Table 1) show that remittances are likely to reduce public education spending in countries suffering from governance problems (regarding the control of corruption, regulation, government effectiveness and accountability). I have not obtained a significant effect for the interaction of remittances crossed with the rule of law and political stability variables even if their coefficients show the expected negative sign.

\section{[Table 1 about here.]}

When I turn on the system-GMM estimator, the results highlight a negative and significant coefficient of the interaction of remittances crossed with each of the six indicators of bad governance (Table 2). It also appears that a high level of government ineffectiveness and a low score on the variable rule of law are the most important sources of public moral hazard effects of remittances. The coefficients of the interactive terms with these variables exhibit the highest absolute values.

\section{[Table 2 about here.]}

Regarding the control variables introduced, the results indicate that the only control variable that is consistently significant is the lagged dependent variable with a relatively high estimated coefficient close to 0.6 across the specifications. It is also worth noting that I have 
obtained higher values of the coefficient associated with the lagged dependent variable in the case of the system-GMM method compared to the values obtained from the standard difference-GMM (Table 1). These results have important implications in the context of GMM estimations. Indeed, given the strong inertia characterizing the dependent variable, there is an obvious "weak instrument" problem in the case of the difference-GMM estimator. This arises because the lagged values of the dependent variable used as instruments do not explain much of the sample variation in the first difference of the dependent variable. ${ }^{11}$ In such a case, the difference-GMM estimate (Arellano and Bond, 1991) is asymptotically close to zero. In contrast, the system-GMM estimator which increases the set of the moment conditions by combining the equations in level with the ones in first difference helps reduce the bias of the difference-GMM estimator. This is why in this paper, the preferred results are clearly those obtained through the system-GMM estimator.

The results also highlight a positive and significant effect of the additive term of remittances in the models. Since the coefficient of this variable identifies the effect of remittances on government spending on education when the governance variable equals 0 , this suggests that remittances increase the level of public expenditure in countries which do not suffer from governance problems. This result can be explained by the impact that remittances can exert on government indirect tax revenues, which help government to finance more public services (Ebeke, 2010b).

\section{Results for public health spending}

The results are presented in Tables 3 and 4. All the diagnostic tests associated with the GMM methodology validate the estimation results. In Table 3, I present the results by using the Arellano-Bond estimator, and the system-GMM results are shown in Table 4. The differenceGMM results of Table 3 validate (in 5 cases out of 6 ) the hypothesis that remittance inflows reduce public health spending in countries experiencing governance problems. ${ }^{12}$ The systemGMM results (Table 4) highlight a fiscal retrenchment in the health sector in 4 cases out of 6. The coefficient of the interactive term of remittances crossed with the governance indicators is not statistically significant in the case of corruption and regulatory quality, even though they exhibit the expected negative sign. In all the remaining cases, the hypothesis that remittances reduce strongly the allocation of public funds into the health sector is not rejected 
by the data. Again, the strongest impact is observed when the variable "Rule of law" is used (column 2).

\section{[Tables 3 and 4 about here.]}

Regarding the control variables, only the lagged dependent variable, the GDP per capita, and the additive term of remittances exhibit statistically significant coefficients in some specifications.

\section{Robustness Checks}

I proceed in three steps to check the robustness of the previous results. Tables of results are reported in the Online appendix.

\section{Adding an external instrument for remittances}

I estimate the models with an augmented system-GMM-IV estimator in which remittances, and remittances crossed with the indicators of governance, are instrumented by their lagged value and by an external instrument borrowed from the recent macro-econometric literature on remittances. Though I do not possess a sufficient number of excluded instruments for it to be possible to apply standard IV techniques, the addition of these external instruments should go some way towards vitiating the potential "weak instruments" problem that often arises in the context of traditional GMM estimation (Arcand et al., 2008). Two external instruments were added: the log-weighted GDP per capita for each of the migrant host countries, and this variable crossed with each indicator of governance quality (Combes and Ebeke, 2011; Aggarwal et al., 2010; Acosta et al., 2009). ${ }^{13}$

\section{Testing for the existence of a common factor representation in the system-GMM-IV estimation}

Consider again the model describing the effect of remittances on public spending conditional on the level of governance:

$$
S_{i, t}=X_{i, t}^{\prime} \beta+\theta_{1} R_{i, t}+\theta_{2} R_{i, t} * G V_{i, t}+\theta_{3} G V_{i, t}+u_{i}+\varepsilon_{i, t}
$$

Suppose that the error term of the model is serially autocorrelated, 


$$
\varepsilon_{i, t}=\sigma \varepsilon_{i, t-1}+v_{i, t} \text { with }|\sigma|<1 \text { and } v_{i, t} \sim \operatorname{MA}(0)
$$

As noted by Blundell and Bond (2000) and Arcand et al. (2008), this type of model has a dynamic common factor representation which involves $\sigma$-differencing the model so as to obtain:

$$
\begin{gathered}
S_{i, t}=\sigma S_{i, t-1}+X_{i, t}^{\prime} \beta+X_{i, t-1}^{\prime} \sigma \beta+\theta_{1} R_{i, t}+\sigma \theta_{1} R_{i, t-1}+\theta_{2} R_{i, t} * G V_{i, t}+\sigma \theta_{2} R_{i, t-1} * G V_{i, t-1}+ \\
\theta_{3} G V_{i, t}+\sigma \theta_{3} G V_{i, t-1}+(1-\sigma) u_{i}+\varepsilon_{i, t}-\sigma \varepsilon_{i, t-1}
\end{gathered}
$$

which can be rewritten as:

$$
\begin{array}{r}
S_{i, t}=\sigma S_{i, t-1}+X_{i, t}^{\prime} \pi_{1}+X_{i, t-1}^{\prime} \pi_{2}+\pi_{3} R_{i, t}+\pi_{4} R_{i, t-1}+\pi_{5} R_{i, t} * G V_{i, t}+\pi_{6} R_{i, t-1} * G V_{i, t-1}+ \\
\pi_{7} G V_{i, t}+\pi_{8} G V_{i, t-1}+\lambda^{*} u_{i}+v_{i, t}
\end{array}
$$

and where the common factor restrictions are given by:

$$
\pi_{l}=-\sigma \pi_{l-1}(l=2,3 \ldots 8) .
$$

Given consistent estimates of the unrestricted parameter vector $\pi_{l}$ and $\operatorname{var}\left(\pi_{l}\right)$, these restrictions can be tested and imposed using minimum distance to obtain the restricted parameter vector $(\beta, \theta, \sigma)$.

Aggregating all the dimensions of governance into a single index using the PCA analysis

I estimate the public spending models using an aggregate index of governance quality which combines all the 6 separate dimensions into a single index. The principal component analysis method is used to achieve this. The aggregate index of governance is the first principal component of the vector of the six indicators of governance already constructed. Table A3 of the Online appendix shows that the first principal component accounts for almost $75 \%$ of the overall variance. The table also presents the eigenvectors and the correlation between the synthetic indicator and each of the variables.

\section{Results of the robustness tests}

In Table A4 (public education spending models) and Table A5 (public health spending models) of the Online appendix, I test the robustness of the results using the augmented system-GMM-IV in which I include the external instrument for remittances, and remittances 
crossed with the indicator of governance. I also test and impose the common factor representation in this system-GMM-IV. The results indicate that the set of the instruments used (the lagged internal instruments and the external instruments) are valid according to the $p$-values of the difference-in-Hansen tests, the second order autocorrelation tests of the residuals in first difference, and to the Hansen over-identification test p-values. Moreover, the test of the common factor restrictions suggests that the null hypothesis that these restrictions are valid cannot be rejected in all cases.

For the public education spending model (Table A4), all the coefficients of the interactive variables exhibit the expected negative signs and are statistically significant. These results confirm the hypothesis that remittance inflows are creating a public moral hazard problem in the public education sector for badly governed countries. The same results are obtained for the case of public health spending (Table A5). However, there remain two instances for which the coefficients of the interactive term are not statistically significant - Regulatory quality and Corruption). This result had already been demonstrated in Table 4.

In Table A6 and Table A7 of the Online appendix, I replace the separate indicators of governance by the composite index of governance derived from the principal component analysis. ${ }^{14}$ In each of Tables A6 and A7, column 1 presents the results obtained by using only internal instruments (lagged value) while column 2 tests the robustness of the results by adding the two external instruments for remittances. Column 3 shows the results obtained by re-estimating the model as in column 2 , but by imposing the common factor representation.

Whatever the specifications, the results highlight a negative and highly significant coefficient of the interactive term of remittances crossed with the composite governance index. Moreover, the range of the estimates of this coefficient is similar to what have been estimated in the previous tables.

I can therefore conclude that even when all the dimensions of governance are combined into a composite index, the finding that remittances reduce public spending on education and health in countries experiencing governance problems still remains, and is highly significant.

\section{Concluding Remarks}

This paper analyses the effect of remittances on public policies in countries affected by governance problems. I tested the hypothesis that governments of badly governed countries 
tend to reduce the level of public spending in social sectors (education and health) when the level of remittances increases. More generally, I argued that remittances create a public moral hazard problem in those developing countries with governance problems. Using a large crosssection of developing countries (86 countries) observed over the recent period 1996-2007, and after factoring in the endogeneity of remittances, the potential effect of remittances on the demand for public services and the other sources of financing for the social sectors, the paper concludes that the remittance-induced fiscal retrenchment in social sectors takes place in developing countries with serious governance problems.

The paper has illustrated how remittances combined with bad public governance might induce a moral hazard problem both on government and households. Indeed, the negative effect of remittances on public spending on social sectors in institutionally vulnerable countries is the combination of two reinforcing effects: $(i)$ public moral hazard - because the government has more incentive to reduce and divert resources, rather than providing subsidies since it thinks that remittances will do the "job". (ii) household moral hazard - because remittances mollify the recipient households which do not have the incentive to monitor the government and so leave the cost of insurance to the migrant. 


\section{References}

Abdih, Y., Dagher, J., Chami, R. and Montiel, P. (2008) Remittances and Institutions: Are Remittances a Curse? IMF Working Papers 08/29, International Monetary Fund.

Acosta, P. A., Baerg, N. R. and Mandelman, F. S. (2009) Financial development, remittances, and real exchange rate appreciation, Economic Review, pp. 1-12.

Adams, R. and Page, J. (2005) Do international migration and remittances reduce poverty in developing countries? World Development, 33(10), pp. 1645-1669.

Aggarwal, R., Demirgüç-Kunt, A. and Martinez-Peria, M. (2010) Do remittances promote financial development? Journal of Development Economics, Forthcoming.

Amuedo-Dorantes, C. and Pozo, S. (2004) Workers' remittances and the real exchange rate: a paradox of gifts. World Development, 32(8), pp. 1407-1417.

Arcand, J., Guillaumont, P. and Guillaumont S. (2008) Deforestation and the real exchange rate. Journal of Development Economics, 86(2), pp. 242-262.

Arellano, M. and Bond, S. (1991). Some Tests of Specification for Panel Data: Monte Carlo Evidence and an Application to Employment Equations. Review of Economic Studies, 58, pp. 277-297.

Arellano, M. and Bover O. (1995). Another Look at the Instrumental Variable Estimation of Error Component Models. Journal of Econometrics 68, pp. 29-51.

Arndt, C. and Oman, C. (2006). Uses and abuses of governance indicators. Paris: OECD Development Centre.

Baqir, R. (2002). Social Spending in a Panel of Countries. IMF Working Paper 02/35, International Monetary Fund.

Blundell, R. and Bond, S. (1998) Initial conditions and moment restrictions in dynamic panel data models. Journal of econometrics, 87(1), pp. 115-143.

Bugamelli, M. and Paternò, F. (2009) Do workers' remittances reduce the probability of current account reversals? World Development, 37(12), pp. 1821-1838. 
Chami, R., Fullenkamp, C. and Jahjah, S. (2003) Are immigrant remittance flows a source of capital for development? IMF Working Papers 03/189, International Monetary Fund.

Chami, R., Fullenkamp, C. and Jahjah, S. (2005) Are immigrant remittance flows a source of capital for development? IMF Staff Papers, 52(1), pp. 55-82.

Chami, R. and Fullenkamp, C. (2009) A Wobbly Crutch. Finance and Development, December 2009. International Monetary Fund.

Chami, R., Hakura, D. and Montiel, P. (2009). Remittances: An Automatic Output Stabilizer? IMF Working Papers 09/91, International Monetary Fund.

Combes, J.-L. and Ebeke, C. (2011) Remittances and household consumption instability in developing countries, World Development, 39(7), Forthcoming.

Docquier, F., Faye, O. and Pestieau, P. (2008) Is migration a good substitute for education subsidies? Journal of Development Economics, 86(2), pp. 263-276.

Ebeke, C. (2011) Remittances, openness and government size. Louvain Economic Review, Forthcoming.

Ebeke, C. (2010a) The effect of remittances on child labor: Cross-country evidence. Economics Bulletin, 30(1), pp. 351-364.

Ebeke, C. (2010b) Remittances, value added tax and tax revenue in developing countries. CERDI-Working Papers 2010/30.

Ebeke, C. and Drabo, A. (2010) Remittances, Public Health Spending and Foreign Aid in the Access to Health Care Services in Developing Countries. CERDI-Working Papers 2010/04.

Feyzioglu, T., Swaroop, V. and Zhu, M. (1998) A panel data analysis of the fungibility of foreign aid. The World Bank Economic Review, 12(1), pp. 29-58.

Fosu, A. (2007) Fiscal allocation for education in sub-Saharan Africa: implications of the external debt service constraint. World Development, 35(4), pp. 702-713.

Fosu, A. (2008) Implications of the external debt-servicing constraint for public health expenditure in Sub-Saharan Africa. Oxford Development Studies, 36(4), pp. 363-377. 
Gbesemete, K. and Gerdtham, U. (1992) Determinants of health care expenditure in Africa: a cross-sectional study. World Development, 20(2), pp. 303-308.

Giuliano, P. and Ruiz-Arranz, M. (2009) Remittances, financial development, and growth. Journal of Development Economics, 90(1), pp. 144-152.

Grabel, I. (2009) Remittances: Political Economy and Developmental Implications. International Journal of Political Economy, 38(4), pp. 86-106.

Gupta, S., Pattillo, C. A. and Wagh, S. (2009) Effect of remittances on poverty and financial development in Sub-Saharan Africa. World Development, 37(1), pp. 104-115.

Hauner, D. and Kyobe, A. (2010). Determinants of government efficiency. World Development, 38(11), pp. 1527-1542.

IMF (2003) World Economic Outlook: Growth and institutions. Washington, DC.

Kapur, D. and Singer, D. (2006) Remittances and Government Spending, and the Global Economy. In Annual Meeting, San Diego, CA.

Kaufmann, D., Kraay, A. and Mastruzzi, M. (2006). The Worldwide Governance Indicators project: Answering the critics. Washington DC: World Bank.

Kaufmann, D., Kraay, A. and Mastruzzi, M. (2009) Governance matters VIII : aggregate and individual governance indicators 1996-2008. Policy Research Working Paper Series 4978, The World Bank.

Kaufmann, D., Kraay, A. and Mastruzzi, M. (2010). Response to "What do the Worldwide Governance Indicators Measure?" The European Journal of Development Research, 22(1), pp. 55-58

Kurtz, M. and Schrank, A. (2006). Growth and governance: Models, measures and mechanisms. Journal of Politics 69(2), pp. 538-554.

Kurtz, M. and Schrank, A. (2007). Growth and governance: A defense. Journal of Politics 69(2), pp. 563-569.

Marchiori, L., Pieretti, P. and Zo, B. (2008) Brain Drain, Remittances, and Fertility. Economie Internationale, 3, pp. 9-42. 
Okunade, A. (2005) Analysis and implications of the determinants of healthcare expenditure in African countries. Health Care Management Science, 8(4), pp. 267-276.

Ratha, D. (2005) Workers' remittances: an important and stable source of external development finance. Remittances: Development Impact and Future Prospects. The World Bank Group.

Ratha, D. (2009) Remittances: A lifeline to poor countries. Finance and Development, December 2009. International Monetary Fund.

Roodman, D. (2009) A Note on the Theme of Too Many Instruments. Oxford Bulletin of Economics and Statistics, 71, pp. 135-158.

Shahbaz, M., Rehman, J. and Hussain, W. (2008) Does Foreign Remittances Reduce Government Spending? Long and Short Run Phenomenon. International Research Journal of Finance and Economics, 14.

Stasavage, D. (2005) Democracy and education spending in Africa. American Journal of Political Science, 49(2), pp. 343-358.

Thomas, M. (2010) What do the Worldwide Governance Indicators Measure? The European Journal of Development Research, 22(1), pp. 31-54.

Yang, D. (2008) International migration, remittances and household investment: Evidence from Philippine migrants' exchange rate shocks. Economic Journal, 118(528), pp. 591-630. 
Table 1: Governance quality, remittances and public education spending, difference-GMM estimation results

\begin{tabular}{|c|c|c|c|c|c|c|}
\hline 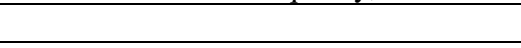 & $(1)$ & $(2)$ & (3) & $(4)$ & $(5)$ & $(6)$ \\
\hline Remittances & $\begin{array}{l}0.145 \\
(1.35)\end{array}$ & $\begin{array}{l}0.060 \\
(0.71)\end{array}$ & $\begin{array}{l}0.062 \\
(1.20)\end{array}$ & $\begin{array}{l}0.105 \\
(1.35)\end{array}$ & $\begin{array}{r}-0.029 \\
(0.58)\end{array}$ & $\begin{array}{l}0.042 \\
(1.11)\end{array}$ \\
\hline Remittances*Corruption & $\begin{array}{c}-0.451^{*} \\
(1.89)\end{array}$ & & & & & \\
\hline Remittances*Rule of law & & $\begin{array}{l}-0.246 \\
(1.23)\end{array}$ & & & & \\
\hline Remittances*Regulatory quality & & & $\begin{array}{r}-0.415^{*} \\
(1.68)\end{array}$ & & & \\
\hline Remittances*Government Effectiveness & & & & $\begin{array}{r}-0.367^{*} \\
(1.73)\end{array}$ & & \\
\hline Remittances*Political stability & & & & & $\begin{array}{l}-0.081 \\
(0.49)\end{array}$ & \\
\hline Remittances*Voice and accountability & & & & & & $\begin{array}{c}-0.242^{* *} \\
(2.61)\end{array}$ \\
\hline Corruption & $\begin{array}{l}-0.719 \\
(0.68)\end{array}$ & & & & & \\
\hline Rule of law & & $\begin{array}{l}-0.428 \\
(0.26)\end{array}$ & & & & \\
\hline Regulatory quality & & & $\begin{array}{l}-1.836 \\
(1.33)\end{array}$ & & & \\
\hline Government Effectiveness & & & & $\begin{array}{l}-0.214 \\
(0.30)\end{array}$ & & \\
\hline Political stability & & & & & $\begin{array}{l}-0.396 \\
(0.44)\end{array}$ & \\
\hline Voice and accountability & & & & & & $\begin{array}{l}-1.008 \\
(1.11)\end{array}$ \\
\hline Lag of the dependent variable & $\begin{array}{c}0.532^{* *} \\
(2.12)\end{array}$ & $\begin{array}{l}0.509^{* *} \\
(2.22)\end{array}$ & $\begin{array}{l}0.313 \\
(1.20)\end{array}$ & $\begin{array}{l}0.550^{* *} \\
(2.42)\end{array}$ & $\begin{array}{l}0.398^{*} \\
(1.89)\end{array}$ & $\begin{array}{l}0.362 \\
(1.61)\end{array}$ \\
\hline Education aid & $\begin{array}{l}0.006 \\
(0.36)\end{array}$ & $\begin{array}{l}0.001 \\
(0.03)\end{array}$ & $\begin{array}{l}0.000 \\
(0.01)\end{array}$ & $\begin{array}{l}0.002 \\
(0.12)\end{array}$ & $\begin{array}{r}-0.000 \\
(0.01)\end{array}$ & $\begin{array}{l}-0.002 \\
(0.13)\end{array}$ \\
\hline GDP per capita & $\begin{array}{l}0.562 \\
(0.67)\end{array}$ & $\begin{array}{l}0.468 \\
(0.66)\end{array}$ & $\begin{array}{l}0.296 \\
(0.37)\end{array}$ & $\begin{array}{l}0.833 \\
(1.24)\end{array}$ & $\begin{array}{l}0.388 \\
(0.78)\end{array}$ & $\begin{array}{l}0.461 \\
(0.79)\end{array}$ \\
\hline Debt service & $\begin{array}{l}0.006 \\
(0.21)\end{array}$ & $\begin{array}{l}0.005 \\
(0.17)\end{array}$ & $\begin{array}{l}-0.029 \\
(0.78)\end{array}$ & $\begin{array}{l}0.015 \\
(0.52)\end{array}$ & $\begin{array}{l}-0.001 \\
(0.06)\end{array}$ & $\begin{array}{l}-0.000 \\
(0.02)\end{array}$ \\
\hline Population aged $<14$ & $\begin{array}{l}0.779 \\
(0.44)\end{array}$ & $\begin{array}{l}0.902 \\
(0.58)\end{array}$ & $\begin{array}{l}0.507 \\
(0.29)\end{array}$ & $\begin{array}{l}1.628 \\
(1.13)\end{array}$ & $\begin{array}{l}0.757 \\
(0.67)\end{array}$ & $\begin{array}{l}0.807 \\
(0.64)\end{array}$ \\
\hline Inflation & $\begin{array}{l}-1.026 \\
(1.15)\end{array}$ & $\begin{array}{r}-0.713 \\
(0.91)\end{array}$ & $\begin{array}{l}-0.931 \\
(1.14)\end{array}$ & $\begin{array}{l}-0.856 \\
(1.09)\end{array}$ & $\begin{array}{l}-0.888 \\
(1.02)\end{array}$ & $\begin{array}{r}-0.812 \\
(1.15)\end{array}$ \\
\hline Urbanization & $\begin{array}{l}1.564^{*} \\
(1.71)\end{array}$ & $\begin{array}{l}1.462^{* *} \\
(2.03)\end{array}$ & $\begin{array}{l}2.200^{*} \\
(1.92)\end{array}$ & $\begin{array}{l}1.319^{*} \\
(1.72)\end{array}$ & $\begin{array}{l}1.570^{* * *} \\
(2.15) \\
\end{array}$ & $\begin{array}{l}1.417^{*} \\
(1.98)\end{array}$ \\
\hline Observations & 433 & 437 & 439 & 439 & 439 & 439 \\
\hline Countries & 77 & 78 & 78 & 78 & 78 & 78 \\
\hline $\begin{array}{l}\text { Joint significance of coefficients of } \\
\text { Remittances., } p \text {-value }\end{array}$ & 0.124 & 0.349 & 0.240 & 0.224 & 0.434 & 0.038 \\
\hline $\mathrm{m} 1: p$-value & 0.055 & 0.065 & 0.182 & 0.045 & 0.110 & 0.083 \\
\hline $\mathrm{m} 2: p$-value & 0.467 & 0.521 & 0.543 & 0.700 & 0.383 & 0.478 \\
\hline Hansen OID test, $p$-value & 0.707 & 0.269 & 0.288 & 0.457 & 0.125 & 0.201 \\
\hline $\mathrm{Nb}$ instruments & 19 & 19 & 19 & 19 & 19 & 19 \\
\hline
\end{tabular}

19

$19 \quad 19 \quad 19$

19

Note: Absolute robust $t$ statistics in parentheses. The governance variables are reverted so that high values indicate a high level of bad governance. All the variables excepting the governance measures are expressed in natural logarithm form. $\mathrm{m} 1$ and $\mathrm{m} 2 p$-values refer to the Arellano and Bond (1991) test of autocorrelation of order 1 and 2 of residuals in first difference, respectively. The one-step difference-GMM is retained to estimate the coefficients. The unit of analysis is the country and the unit of observation is the year. Remittances and remittances crossed with the governance variables are treated as predetermined and therefore instrumented by their lagged values. Dependent variable: $\log$ of public education spending-to-GDP. ${ }^{*} p<0.10,{ }^{* *} p<0.05,{ }^{* * *} p<0.01$. 
Table 2 : Governance quality, remittances and public education spending, system-GMM estimation results

\begin{tabular}{|c|c|c|c|c|c|c|}
\hline & $(1)$ & $(2)$ & (3) & $(4)$ & $(5)$ & $(6)$ \\
\hline Remittances & $\begin{array}{l}0.072 \\
(1.35)\end{array}$ & $\begin{array}{l}0.153^{*} \\
(1.70)\end{array}$ & $\begin{array}{l}0.063^{*} \\
(1.85)\end{array}$ & $\begin{array}{l}0.113 \\
(1.60)\end{array}$ & $\begin{array}{l}0.047^{*} \\
(1.73)\end{array}$ & $\begin{array}{c}0.086^{* * *} \\
(2.11)\end{array}$ \\
\hline Remittances*Corruption & $\begin{array}{c}-0.169^{*} \\
(1.72)\end{array}$ & & & & & \\
\hline Remittances*Rule of law & & $\begin{array}{c}-0.386^{* *} \\
(2.03)\end{array}$ & & & & \\
\hline Remittances*Regulatory quality & & & $\begin{array}{c}-0.220^{* * *} \\
(2.47)\end{array}$ & & & \\
\hline Remittances*Government Effectiveness & & & & $\begin{array}{c}-0.306^{* *} \\
(2.05)\end{array}$ & & \\
\hline Remittances*Political stability & & & & & $\begin{array}{c}-0.206^{* *} \\
(2.24)\end{array}$ & \\
\hline Remittances*Voice and accountability & & & & & & $\begin{array}{c}-0.256^{* * * *} \\
(2.65)\end{array}$ \\
\hline Corruption & $\begin{array}{l}-0.359 \\
(1.58)\end{array}$ & & & & & \\
\hline Rule of law & & $\begin{array}{l}-0.433 \\
(1.19)\end{array}$ & & & & \\
\hline Regulatory quality & & & $\begin{array}{l}-0.198 \\
(0.95)\end{array}$ & & & \\
\hline Government Effectiveness & & & & $\begin{array}{l}-0.532 \\
(1.56)\end{array}$ & & \\
\hline Political stability & & & & & $\begin{array}{l}-0.189 \\
(0.92)\end{array}$ & \\
\hline Voice and accountability & & & & & & $\begin{array}{l}-0.311 \\
(1.45)\end{array}$ \\
\hline Lag of the dependent variable & $\begin{array}{c}0.665^{* * * *} \\
(3.72)\end{array}$ & $\begin{array}{c}0.643^{\text {*** }} \\
(3.54)\end{array}$ & $\begin{array}{c}0.657^{* * * *} \\
(3.62)\end{array}$ & $\begin{array}{c}0.683^{* * * *} \\
(3.82)\end{array}$ & $\begin{array}{c}0.662^{* * *} \\
(3.99)\end{array}$ & $\begin{array}{c}0.645^{* * * *} \\
(3.41)\end{array}$ \\
\hline Education aid & $\begin{array}{l}0.009 \\
(0.53)\end{array}$ & $\begin{array}{l}0.006 \\
(0.35)\end{array}$ & $\begin{array}{l}0.011 \\
(0.65)\end{array}$ & $\begin{array}{l}0.007 \\
(0.45)\end{array}$ & $\begin{array}{l}0.006 \\
(0.41)\end{array}$ & $\begin{array}{l}0.007 \\
(0.41)\end{array}$ \\
\hline GDP per capita & $\begin{array}{l}0.001 \\
(0.03)\end{array}$ & $\begin{array}{l}0.014 \\
(0.32)\end{array}$ & $\begin{array}{l}0.025 \\
(0.51)\end{array}$ & $\begin{array}{l}-0.012 \\
(0.32)\end{array}$ & $\begin{array}{l}0.030 \\
(0.67)\end{array}$ & $\begin{array}{l}0.005 \\
(0.12)\end{array}$ \\
\hline Debt service & $\begin{array}{l}0.002 \\
(0.08)\end{array}$ & $\begin{array}{l}-0.017 \\
(0.67)\end{array}$ & $\begin{array}{l}0.004 \\
(0.16)\end{array}$ & $\begin{array}{l}-0.009 \\
(0.45)\end{array}$ & $\begin{array}{l}0.006 \\
(0.23)\end{array}$ & $\begin{array}{l}-0.003 \\
(0.10)\end{array}$ \\
\hline Population aged $<14$ & $\begin{array}{r}-0.012 \\
(0.09)\end{array}$ & $\begin{array}{r}-0.011 \\
(0.07)\end{array}$ & $\begin{array}{r}-0.002 \\
(0.01)\end{array}$ & $\begin{array}{r}-0.006 \\
(0.04)\end{array}$ & $\begin{array}{c}-0.033 \\
(0.26)\end{array}$ & $\begin{array}{c}-0.030 \\
(0.20)\end{array}$ \\
\hline Inflation & $\begin{array}{c}-0.715^{* * *} \\
(2.98)\end{array}$ & $\begin{array}{c}-0.761^{* * * *} \\
(3.32)\end{array}$ & $\begin{array}{c}-0.624^{* * *} \\
(2.74)\end{array}$ & $\begin{array}{c}-0.671^{* * * *} \\
(2.91)\end{array}$ & $\begin{array}{c}-0.595^{* *} \\
(2.52)\end{array}$ & $\begin{array}{c}-0.677^{* * * *} \\
(2.90)\end{array}$ \\
\hline Urbanization & $\begin{array}{l}0.014 \\
(0.23)\end{array}$ & $\begin{array}{l}0.009 \\
(0.13)\end{array}$ & $\begin{array}{l}0.000 \\
(0.01)\end{array}$ & $\begin{array}{c}0.028 \\
(0.51)\end{array}$ & $\begin{array}{l}-0.038 \\
(0.58)\end{array}$ & $\begin{array}{l}0.005 \\
(0.08)\end{array}$ \\
\hline Intercept & $\begin{array}{l}0.725 \\
(1.11) \\
\end{array}$ & $\begin{array}{l}0.719 \\
(0.89) \\
\end{array}$ & $\begin{array}{l}0.451 \\
(0.67) \\
\end{array}$ & $\begin{array}{l}0.765 \\
(1.09) \\
\end{array}$ & $\begin{array}{l}0.661 \\
(1.03) \\
\end{array}$ & $\begin{array}{l}0.752 \\
(1.06) \\
\end{array}$ \\
\hline Observations & 537 & 541 & 543 & 543 & 543 & 543 \\
\hline Countries & 80 & 80 & 80 & 80 & 80 & 80 \\
\hline $\begin{array}{l}\text { Joint significance of coefficients of } \\
\text { Remittances., } p \text {-value }\end{array}$ & 0.143 & 0.070 & 0.033 & 0.035 & 0.084 & 0.030 \\
\hline $\mathrm{m} 1: p$-value & 0.001 & 0.001 & 0.001 & 0.000 & 0.000 & 0.001 \\
\hline $\mathrm{m} 2: p$-value & 0.644 & 0.660 & 0.670 & 0.717 & 0.719 & 0.724 \\
\hline Hansen OID test, $p$-value & 0.736 & 0.595 & 0.610 & 0.624 & 0.536 & 0.535 \\
\hline Difference-in-Hansen test, $p$-value & 0.832 & 0.366 & 0.937 & 0.541 & 0.539 & 0.292 \\
\hline $\mathrm{Nb}$ instruments & 27 & 27 & 27 & 27 & 27 & 27 \\
\hline
\end{tabular}

Note: Absolute robust $t$ statistics in parentheses. The governance variables are reverted so that high values indicate a high level of bad governance. All the variables excepting the governance measures are expressed in natural logarithm form. $\mathrm{m} 1$ and $\mathrm{m} 2 p$-values refer to the Arellano and Bond (1991) test of autocorrelation of order 1 and 2 of residuals in first difference, respectively. The one-step systemGMM is retained to estimate the coefficients. Difference-in-Hansen test reports the $p$-values based on the null hypothesis that the instruments in the levels equation are exogenous. The unit of analysis is the country and the unit of observation is the year. Remittances and remittances crossed with the governance variables are treated as predetermined and therefore instrumented by their lagged values. Dependent variable: $\log$ of public education spending-to-GDP. ${ }^{*} p<0.10,{ }^{* * *} p<0.05,{ }^{* * * *} p<0.01$. 
Table 3: Governance quality, remittances and public health spending, difference-GMM estimation results

\begin{tabular}{|c|c|c|c|c|c|c|}
\hline 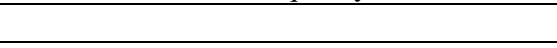 & $(1)$ & $(2)$ & (3) & $(4)$ & $(5)$ & $(6)$ \\
\hline Remittances & $\begin{array}{c}0.152^{*} \\
(1.68)\end{array}$ & $\begin{array}{l}0.113 \\
(1.46)\end{array}$ & $\begin{array}{l}0.022 \\
(0.31)\end{array}$ & $\begin{array}{c}0.109^{* * *} \\
(2.44)\end{array}$ & $\begin{array}{l}0.036 \\
(0.58)\end{array}$ & $\begin{array}{l}0.047 \\
(0.70)\end{array}$ \\
\hline Remittances*Corruption & $\begin{array}{c}-0.516^{* * *} \\
(2.22)\end{array}$ & & & & & \\
\hline Remittances*Rule of law & & $\begin{array}{c}-0.404^{*} \\
(1.71)\end{array}$ & & & & \\
\hline Remittances*Regulatory quality & & & $\begin{array}{c}-0.143 \\
(0.40)\end{array}$ & & & \\
\hline Remittances*Government Effectiveness & & & & $\begin{array}{c}-0.469^{* *} \\
(2.50)\end{array}$ & & \\
\hline Remittances*Political stability & & & & & $\begin{array}{c}-0.354^{*} \\
(1.78)\end{array}$ & \\
\hline Remittances*Voice and accountability & & & & & & $\begin{array}{c}-0.392^{* * *} \\
(2.56)\end{array}$ \\
\hline Corruption & $\begin{array}{l}0.097 \\
(0.08)\end{array}$ & & & & & \\
\hline Rule of law & & $\begin{array}{l}-1.259 \\
(0.65)\end{array}$ & & & & \\
\hline Regulatory quality & & & $\begin{array}{l}0.680 \\
(0.96)\end{array}$ & & & \\
\hline Government Effectiveness & & & & $\begin{array}{l}-0.656 \\
(0.49)\end{array}$ & & \\
\hline Political stability & & & & & $\begin{array}{l}-1.040 \\
(0.98)\end{array}$ & \\
\hline Voice and accountability & & & & & & $\begin{array}{l}-0.117 \\
(0.07)\end{array}$ \\
\hline Lag dependent variable & $\begin{array}{c}0.682^{* * * *} \\
(3.66)\end{array}$ & $\begin{array}{c}0.666^{* * * *} \\
(2.74)\end{array}$ & $\begin{array}{l}0.396 \\
(1.49)\end{array}$ & $\begin{array}{c}0.623^{* * * *} \\
(3.22)\end{array}$ & $\begin{array}{c}0.723^{* * * *} \\
(2.87)\end{array}$ & $\begin{array}{l}0.535^{* * *} \\
(2.04)\end{array}$ \\
\hline Health aid & $\begin{array}{c}-0.005 \\
(0.15)\end{array}$ & $\begin{array}{l}0.005 \\
(0.16)\end{array}$ & $\begin{array}{l}0.000 \\
(0.00)\end{array}$ & $\begin{array}{l}0.006 \\
(0.22)\end{array}$ & $\begin{array}{c}-0.014 \\
(0.34)\end{array}$ & $\begin{array}{l}0.016 \\
(0.43)\end{array}$ \\
\hline Debt service & $\begin{array}{l}0.034 \\
(0.86)\end{array}$ & $\begin{array}{l}0.027 \\
(0.66)\end{array}$ & $\begin{array}{l}0.046 \\
(1.08)\end{array}$ & $\begin{array}{l}0.049 \\
(1.41)\end{array}$ & $\begin{array}{l}0.041 \\
(0.98)\end{array}$ & $\begin{array}{l}0.017 \\
(0.37)\end{array}$ \\
\hline GDP per capita & $\begin{array}{l}-0.440 \\
(0.90)\end{array}$ & $\begin{array}{l}-0.639 \\
(1.30)\end{array}$ & $\begin{array}{l}-0.052 \\
(0.12)\end{array}$ & $\begin{array}{l}-0.657 \\
(1.32)\end{array}$ & $\begin{array}{l}-0.514 \\
(1.12)\end{array}$ & $\begin{array}{l}-0.554 \\
(0.78)\end{array}$ \\
\hline Inflation rate & $\begin{array}{l}-0.597 \\
(0.94)\end{array}$ & $\begin{array}{l}-0.803 \\
(1.31)\end{array}$ & $\begin{array}{l}-0.482 \\
(1.03)\end{array}$ & $\begin{array}{l}-0.553 \\
(1.12)\end{array}$ & $\begin{array}{l}-0.515 \\
(0.96)\end{array}$ & $\begin{array}{l}-0.278 \\
(0.51)\end{array}$ \\
\hline Population growth & $\begin{array}{c}0.216^{* * *} \\
(2.09)\end{array}$ & $\begin{array}{l}0.176 \\
(1.65)\end{array}$ & $\begin{array}{l}0.080 \\
(0.83)\end{array}$ & $\begin{array}{l}0.150^{*} \\
(1.71)\end{array}$ & $\begin{array}{l}0.145 \\
(1.65)\end{array}$ & $\begin{array}{l}0.229 \\
(1.00)\end{array}$ \\
\hline Urbanization & $\begin{array}{l}0.769 \\
(0.88)\end{array}$ & $\begin{array}{l}0.976 \\
(1.57)\end{array}$ & $\begin{array}{l}0.682 \\
(0.82)\end{array}$ & $\begin{array}{l}1.051 \\
(1.57)\end{array}$ & $\begin{array}{l}1.506^{*} \\
(1.86)\end{array}$ & $\begin{array}{l}0.492 \\
(0.39)\end{array}$ \\
\hline Observations & 464 & 467 & 469 & 469 & 467 & 469 \\
\hline Countries & 83 & 84 & 85 & 85 & 85 & 85 \\
\hline $\begin{array}{l}\text { Joint significance of coefficients of } \\
\text { Remittances., } p \text {-value }\end{array}$ & 0.084 & 0.231 & 0.922 & 0.032 & 0.189 & 0.035 \\
\hline $\mathrm{m} 1: p$-value & 0.003 & 0.012 & 0.077 & 0.005 & 0.010 & 0.033 \\
\hline $\mathrm{m} 2: p$-value & 0.308 & 0.293 & 0.325 & 0.222 & 0.247 & 0.313 \\
\hline Hansen OID test, $p$-value & 0.810 & 0.616 & 0.283 & 0.658 & 0.520 & 0.594 \\
\hline $\mathrm{Nb}$ instruments & 19 & 19 & 19 & 19 & 19 & 19 \\
\hline
\end{tabular}

$\mathrm{Nb}$ instruments

$19 \quad 19$

$19 \quad 19 \quad 19$

Note -Absolute robust $t$ statistics in parentheses. The governance variables are reverted so that high values indicate a high level of bad governance. All the variables excepting the governance measures are expressed in natural logarithm form. $\mathrm{m} 1 \mathrm{and} \mathrm{m} 2 p$-values refer to the Arellano and Bond (1991) test of autocorrelation of order 1 and 2 of residuals in first difference, respectively. The one-step difference-GMM is retained to estimate the coefficients. The unit of analysis is the country and the unit of observation is the year. Remittances and remittances crossed with the governance variables are treated as predetermined and therefore instrumented by their lagged values. Dependent variable: log of public health spending-to-GDP. ${ }^{*} p<0.10,{ }^{* *} p<0.05,{ }^{* * *} p<0.01$. 
Table 4 : Governance quality, remittances and public health spending, system-GMM estimation results

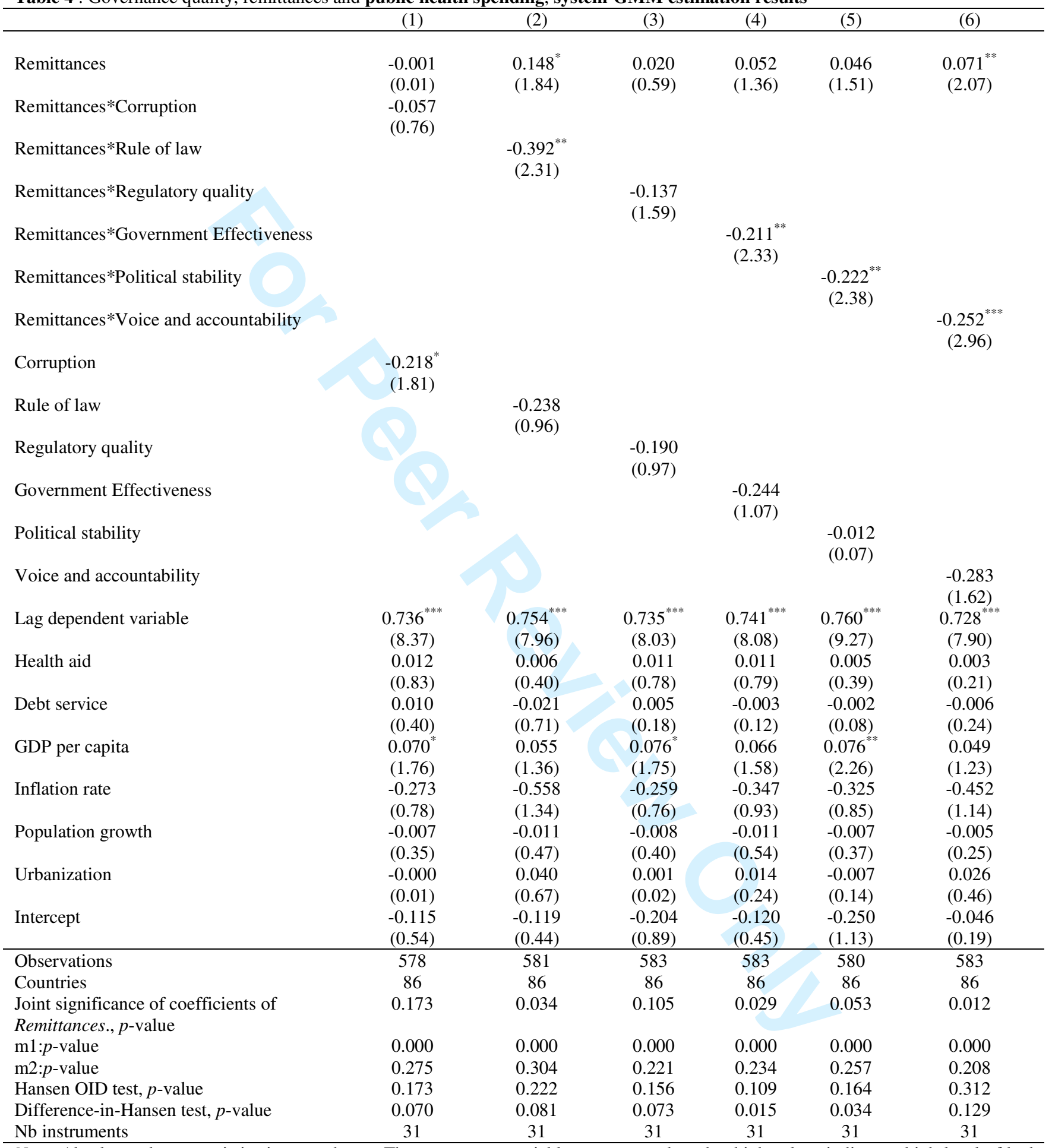

Note: Absolute robust $t$ statistics in parentheses. The governance variables are reverted so that high values indicate a high level of bad governance. All the variables excepting the governance measures are expressed in natural logarithm form. $\mathrm{m} 1$ and $\mathrm{m} 2 p$-values refer to the Arellano and Bond (1991) test of autocorrelation of order 1 and 2 of residuals in first difference, respectively. The one-step systemGMM is retained to estimate the coefficients. Difference-in-Hansen test reports the $p$-values based on the null hypothesis that the instruments in the levels equation are exogenous. The unit of analysis is the country and the unit of observation is the year. Remittances and remittances crossed with the governance variables are treated as predetermined and therefore instrumented by their lagged values. Dependent variable: log of public health spending-to-GDP. ${ }^{*} p<0.10,{ }^{* * *} p<0.05,{ }^{* * * *} p<0.01$. 


\section{Notes}

${ }^{1} G$ is an indicator of governance quality with high values corresponding to a bad governance score.

${ }^{2}$ Docquier et al. (2008) have recently shown in a cross-sectional analysis, a negative impact of skilled migration on public subsidies for education: the average elasticity of public education subsidies to skilled migration rates amounts to -0.20 .

${ }^{3}$ The Anderson-Hsiao estimator (A-H) is another estimator that can be used to estimate this type of dynamic panel model. The A-H estimator specifies the original model in its first difference form and instruments the endogenous variables with their lagged values. Although the A-H estimator is simple to implement, the major concern is that the autocorrelation of the residuals in first difference is not taken into account and tested. This is why the dynamic panel GMM estimators (Arellano and Bond, 1991; Blundell and Bond, 1998) are useful since they resort to the generalized method of moments to estimate the parameters. This method dominates in efficiency the traditional 2SLS (the procedure used in the implementation of the A-H estimator) in the case of non-spherical perturbations (heteroskedasticity and autocorrelation of unknown forms). I tried to estimate all the models using the A-H estimator but I obtained unreliable results with no significant coefficients for all the explanatory variables.

${ }^{4}$ Baqir (2002) and Gomanee et al. (2005) also used these categories of public spending as proxies for pro-poor public expenditures.

${ }^{5}$ These data have been previously used by Baqir (2002) and Hauner and Kyobe (2010).

${ }^{6} \mathrm{CRS}$ data is available at:

http://www.oecd.org/document/0/0,2340,en_2649_34447_37679488_1_1_1_1,00.html

${ }^{7}$ The CRS also provides a disaggregation of disbursements by sector. Unfortunately disbursements are even more underreported than commitments.

${ }^{8}$ The relationship between migration, remittances and the fertility of recipient households has been addressed by (Marchiori et al., 2008).

${ }^{9}$ Catrinescu et al. (2009) pointed out that 'good' institutions are viewed as establishing an incentive structure that reduces uncertainty and promotes efficiency - so contributing to stronger economic performance. The IMF (2003) recognizes that development-positive institutions are those that protect private property rights and the operation of the rule of law; lead to low levels of corruption; and facilitate all private interactions rather than protect a small elite. Overall, I assess that a country is vulnerable when its level of governance quality is low according to the measures of governance quality published in the empirical literature.

${ }^{10}$ Kaufmann, Kraay, and Mastruzzi (2009) construct a meta-indicator that aggregates a host of different measures, from firm, investor, and population surveys to expert and international organization assessments to come to their overall measurements of the quality of governance. Data are available at the Worldwide Governance Indicators (WGI) project website under the following address:

http://info.worldbank.org/governance/wgi/index.asp

For more details on the construction of the indices, refer to Kaufmann, Kraay and Mastruzzi (2009). “Governance Matters VIII: Aggregate and Individual Governance Indicators, 1996-2008”. World Bank Policy Research Working Paper Series, 4978. 


\footnotetext{
${ }^{11}$ This is also the case for the remittance variable which is recognized to have a strong inertia due to the high stability that the flow exhibits over the time.

${ }^{12}$ The only case for which the coefficient of the interaction term is not significant is the specification using the regulatory quality.

${ }^{13}$ I computed the GDP per capita in the migrants' host countries by weighting the GDP per capita of all other countries by the share that each of these countries represents in the emigration of workers of developing countries. The bilateral migration matrix used to make calculations was drawn from the World Bank web site:

http://econ.worldbank.org/WBSITE/EXTERNAL/EXTDEC/EXTDECPROSPECTS/0,,contentMDK:21154867 pagePK:64165401 piPK:64165026 theSitePK:476883,00.html

${ }^{14}$ The aggregate index is rescaled so that the variable is between 0 and 1.
} 


\section{Do Remittances Lead to a Public Moral Hazard in Developing Countries?}

\section{An Empirical Investigation}

\section{CHRISTIAN HUBERT EBEKE}

Clermont Université, Université d'Auvergne, Centre d'Etudes et de Recherches sur le Développement International, BP 10448, F-63000 CLERMONT-FERRAND. FRANCE

\section{Online appendix}


Table A1: Descriptive statistics

\begin{tabular}{|c|c|c|c|c|c|}
\hline Variables & Obs & Mean & Std. Dev. & Min & Max \\
\hline \multicolumn{6}{|l|}{ Governance measures } \\
\hline Corruption & 1664 & 0.58 & 0.17 & 0 & 1 \\
\hline Rule of law & 1692 & 0.51 & 0.15 & 0 & 1 \\
\hline Regulatory quality & 1716 & 0.43 & 0.16 & 0 & 1 \\
\hline Government Effectiveness & 1716 & 0.48 & 0.16 & 0 & 1 \\
\hline Political stability & 1684 & 0.40 & 0.19 & 0 & 1 \\
\hline Voice and accountability & 1730 & 0.49 & 0.22 & 0 & 1 \\
\hline Composite index & 1636 & 0.47 & 0.16 & 0 & 1 \\
\hline GDP per capita (log) & 1688 & 6.94 & 1.09 & 4.19 & 9.20 \\
\hline Education aid (\% GDP) (log) & 1572 & -1.60 & 1.94 & -10.32 & 2.91 \\
\hline Health aid (\% GDP) (log) & 1519 & -1.91 & 2.39 & -11.54 & 2.73 \\
\hline Debt service (\% GDP) (log) & 1524 & 1.24 & 0.94 & -2.94 & 4.91 \\
\hline Population aged <14 (\%) (log) & 1703 & 3.54 & 0.28 & 2.60 & 3.91 \\
\hline Population growth rate (\%) & 1795 & 1.59 & 1.25 & -10.96 & 9.09 \\
\hline $\log (100+$ Inflation rate $)$ & 1709 & 0.10 & 0.20 & -0.27 & 4.01 \\
\hline Urbanization rate $(\log )$ & 1783 & 3.73 & 0.51 & 2.00 & 4.54 \\
\hline Public education spending (\% GDP) (log) & 1065 & 1.33 & 0.54 & -1.29 & 3.14 \\
\hline Public health spending (\%GDP) (log) & 1143 & 0.63 & 0.70 & -1.76 & 2.76 \\
\hline Remittances (\% GDP) (log) & 1113 & 0.35 & 2.07 & -10.19 & 3.90 \\
\hline
\end{tabular}


Table A2: List of countries in the sample (86)

\begin{tabular}{lllll}
\hline Albania & Dominica & Kenya & Papua New Guinea & Ukraine \\
Argentina & Dominican Rep. & Kyrgyz Rep. & Paraguay & Uruguay \\
Armenia & Ecuador & Lebanon & Peru & Vanuatu \\
Azerbaijan & Egypt & Lesotho & Philippines & Venezuela \\
Bangladesh & El Salvador & Liberia & Senegal & Yemen, Rep. \\
Belize & Ethiopia & Madagascar & Seychelles & Zambia \\
Benin & Fiji & Malawi & Sierra Leone & \\
Bolivia & Gabon & Mali & Sri Lanka & \\
Bosnia and Herzegovina & Gambia & Mauritania & St. Kitts and Nevis & \\
Botswana & Georgia & Mexico & St. Lucia & \\
Brazil & Ghana & Moldova & St. Vincent and the Grenadines \\
Burkina Faso & Grenada & Mongolia & Sudan & \\
Burundi & Guatemala & Morocco & Swaziland & \\
Cambodia & Guinea & Mozambique & Tajikistan & \\
Cameroon & Guinea-Bissau & Nepal & Tanzania & \\
Cape Verde & Honduras & Nicaragua & Togo \\
Colombia & India & Niger & Tonga \\
Costa Rica & Jamaica & Nigeria & Tunisia \\
Cote d'Ivoire & Jordan & Pakistan & Turkey \\
Djibouti & Kazakhstan & Panama & Uganda & \\
\hline & & &
\end{tabular}


Table A3: Aggregating governance variables: principal components analysis (first eigenvector, correlation)

\begin{tabular}{|c|c|}
\hline Variables & $\begin{array}{l}\text { Governance quality, } \\
\text { Composite index }\end{array}$ \\
\hline Control of corruption & $\begin{array}{c}0.423 \\
(0.899)\end{array}$ \\
\hline Rule of law & $\begin{array}{c}0.437 \\
(0.930)\end{array}$ \\
\hline Regulatory quality & $\begin{array}{c}0.405 \\
(0.860)\end{array}$ \\
\hline Government effectiveness & $\begin{array}{c}0.430 \\
(0.913)\end{array}$ \\
\hline Political stability & $\begin{array}{c}0.363 \\
(0.771)\end{array}$ \\
\hline Voice and Accountability & $\begin{array}{c}0.386 \\
(0.821)\end{array}$ \\
\hline $\begin{array}{l}\text { Eigenvalue } \\
\text { Variance proportion }\end{array}$ & \\
\hline \multicolumn{2}{|c|}{$\begin{array}{l}\text { Note: I report the first eigenvector resulting from the first principa } \\
\text { component analysis of governance quality. The aggregate index of } \\
\text { governance is obtained using the following formula: } \mathrm{GV}= \\
0.423 * \mathrm{~K} 1+0.437 * \mathrm{~K} 2+0.405 * \mathrm{~K} 3+0.430 * \mathrm{~K} 4+0.363 * \mathrm{~K} 5+ \\
0.386 * \mathrm{~K} 6 \text {, where } \mathrm{K} 1, \mathrm{~K} 2, \mathrm{~K} 3, \mathrm{~K} 4, \mathrm{~K} 5, \text { and } \mathrm{K} 6 \text { represent } \\
\text { standardized measures of Control of corruption, Rule of law, } \\
\text { Regulatory quality, Government effectiveness, Political stability, } \\
\text { and Political stability, respectively. In addition, the numbers in } \\
\text { parentheses (below the different eigenvectors) represent the } \\
\text { correlation of the first principal component with the corresponding } \\
\text { governance variable. The governance quality variables have been } \\
\text { rescaled so that high values indicate high level of bad governance. }\end{array}$} \\
\hline
\end{tabular}


Table A4: Governance quality, remittances and public education spending, system-GMM-IV with a Common Factor representation.

\begin{tabular}{|c|c|c|c|c|c|c|}
\hline & $(1)$ & $(2)$ & (3) & $(4)$ & $(5)$ & $(6)$ \\
\hline Remittances & $\begin{array}{l}0.033 \\
(0.94)\end{array}$ & $\begin{array}{l}0.103^{* *} \\
(1.97)\end{array}$ & $\begin{array}{c}0.045 \\
(0.709)\end{array}$ & $\begin{array}{c}0.095^{* *} \\
(2.51)\end{array}$ & $\begin{array}{l}0.013 \\
(0.45)\end{array}$ & $\begin{array}{l}0.058^{*} \\
(1.83)\end{array}$ \\
\hline Remittances*Corruption & $\begin{array}{c}-0.136^{*} \\
(1.67)\end{array}$ & & & & & \\
\hline Remittances*Rule of law & & $\begin{array}{c}-0.359^{* *} \\
(2.55)\end{array}$ & & & & \\
\hline Remittances*Regulatory quality & & & $\begin{array}{c}-0.245^{*} \\
(1.64)\end{array}$ & & & \\
\hline Remittances*Government Effectiveness & & & & $\begin{array}{c}-0.319^{* * * *} \\
(2.95)\end{array}$ & & \\
\hline Remittances*Political stability & & & & & $\begin{array}{c}-0.211^{* * *} \\
(2.04)\end{array}$ & \\
\hline Remittances*Voice and accountability & & & & & & $\begin{array}{c}-0.228^{* * * *} \\
(3.38)\end{array}$ \\
\hline Corruption & $\begin{array}{l}-0.081 \\
(0.44)\end{array}$ & & & & & \\
\hline Rule of law & & $\begin{array}{l}-0.097 \\
(0.308)\end{array}$ & & & & \\
\hline Regulatory quality & & & $\begin{array}{l}0.026 \\
(0.08)\end{array}$ & & & \\
\hline Government Effectiveness & & & & $\begin{array}{l}-0.258 \\
(0.89)\end{array}$ & & \\
\hline Political stability & & & & & $\begin{array}{l}0.345 \\
(1.30)\end{array}$ & \\
\hline Voice and accountability & & & & & & $\begin{array}{c}-0.013 \\
(0.05)\end{array}$ \\
\hline Lag of the dependent variable & $\begin{array}{c}0.954^{* * *} \\
(87.97)\end{array}$ & $\begin{array}{c}0.943^{\text {**** }} \\
(93.70)\end{array}$ & $\begin{array}{c}0.942^{* * * *} \\
(75.78)\end{array}$ & $\begin{array}{l}0.949^{* * * *} \\
(109.13)\end{array}$ & $\begin{array}{c}0.953^{* * * *} \\
(84.62)\end{array}$ & $\begin{array}{c}0.952^{* * * * *} \\
(88.71)\end{array}$ \\
\hline Observations & 421 & 427 & 430 & 430 & 430 & 430 \\
\hline Countries & 75 & 76 & 76 & 76 & 76 & 76 \\
\hline $\mathrm{m} 1: p$-value & 0.013 & 0.013 & 0.002 & 0.016 & 0.009 & 0.005 \\
\hline $\mathrm{m} 2: p$-value & 0.667 & 0.608 & 0.967 & 0.622 & 0.513 & 0.517 \\
\hline Hansen OID test, $p$-value & 0.536 & 0.411 & 0.243 & 0.513 & 0.181 & 0.367 \\
\hline Difference-in-Hansen test, $p$-value & 0.486 & 0.589 & 0.190 & 0.635 & 0.315 & 0.377 \\
\hline Comfac, $p$-value & 0.581 & 0.835 & 0.868 & 0.961 & 0.484 & 0.589 \\
\hline $\mathrm{Nb}$ instruments & 35 & 35 & 35 & 35 & 35 & 35 \\
\hline
\end{tabular}

$\mathrm{Nb}$ instrument

$35 \quad 35$

35

35

35

35

Note: Absolute robust $t$ statistics in parentheses. Control variables are included in all the models but are not reported. Comfac is a minimum distance test of the non-linear common factor restrictions imposed in the restricted models. $P$-values are reported. Differencein-Hansen test reports the $p$-values based on the null hypothesis that the instruments in the levels equation are exogenous. The governance variables are reverted so that high values indicate a high level of bad governance. All the variables excepting the governance measures are expressed in natural logarithm form. $\mathrm{m} 1$ and $\mathrm{m} 2 p$-values refer to the Arellano and Bond (1991) test of autocorrelation of order 1 and 2 of residuals in first difference, respectively. The one-step system-GMM is retained to estimate the coefficients. The unit of analysis is the country and the unit of observation is the year. Remittances and remittances crossed with the governance variables are treated as predetermined and therefore instrumented by their lagged values. The log of the GDP per capita in the host countries and this variable crossed with the indicators of governance are added in the instrument matrix. Dependent variable: log of public education spending-to-GDP ${ }^{*} p<0.10,{ }^{* *} p<0.05,{ }^{* * *} p<0.01$. 
Table A5: Governance quality, remittances and public health spending, system-GMM-IV with a Common Factor representation.

\begin{tabular}{|c|c|c|c|c|c|c|}
\hline & $(1)$ & $(2)$ & (3) & $(4)$ & $(5)$ & $(6)$ \\
\hline Remittances & $\begin{array}{c}0.022 \\
(0.842)\end{array}$ & $\begin{array}{l}0.057^{*} \\
(1.70)\end{array}$ & $\begin{array}{l}0.010 \\
(0.32)\end{array}$ & $\begin{array}{c}0.055^{* * *} \\
(2.63)\end{array}$ & $\begin{array}{l}0.008 \\
(0.37)\end{array}$ & $\begin{array}{c}0.047^{* * *} \\
(3.03)\end{array}$ \\
\hline Remittances*Corruption & $\begin{array}{c}-0.063 \\
(1.03)\end{array}$ & & & & & \\
\hline Remittances*Rule of law & & $\begin{array}{c}-0.178^{* * *} \\
(1.96)\end{array}$ & & & & \\
\hline Remittances*Regulatory quality & & & $\begin{array}{l}-0.093 \\
(1.15)\end{array}$ & & & \\
\hline Remittances*Government Effectiveness & & & & $\begin{array}{c}-0.187^{* * * *} \\
(2.94)\end{array}$ & & \\
\hline Remittances*Political stability & & & & & $\begin{array}{c}-0.116^{* *} \\
(2.43)\end{array}$ & \\
\hline Remittances*Voice and accountability & & & & & & $\begin{array}{c}-0.190^{* * * *} \\
(3.77)\end{array}$ \\
\hline Corruption & $\begin{array}{c}-1.002^{* * *} \\
(2.88)\end{array}$ & & & & & \\
\hline Rule of law & & $\begin{array}{c}-1.137^{*} \\
(1.88)\end{array}$ & & & & \\
\hline Regulatory quality & & & $\begin{array}{l}0.048 \\
(0.09)\end{array}$ & & & \\
\hline Government Effectiveness & & & & $\begin{array}{l}-0.570 \\
(1.30)\end{array}$ & & \\
\hline Political stability & & & & & $\begin{array}{l}-0.272 \\
(0.67)\end{array}$ & \\
\hline Voice and accountability & & & & & & $\begin{array}{c}-0.822^{*} \\
(1.86)\end{array}$ \\
\hline Lag of the dependent variable & $\begin{array}{c}0.802^{* * *} \\
(13.05) \\
\end{array}$ & $\begin{array}{c}0.749^{* * * *} \\
(8.53) \\
\end{array}$ & $\begin{array}{c}0.777^{* * * *} \\
(11.00)\end{array}$ & $\begin{array}{c}0.739^{* * * *} \\
(9.40) \\
\end{array}$ & $\begin{array}{c}0.806^{* * *} \\
(11.77) \\
\end{array}$ & $\begin{array}{c}0.735^{\text {**** }} \\
(8.67) \\
\end{array}$ \\
\hline Observations & 532 & 538 & 539 & 539 & 537 & 539 \\
\hline Countries & 81 & 82 & 82 & 82 & 82 & 82 \\
\hline $\mathrm{m} 1: p$-value & 0.000 & 0.000 & 0.000 & 0.000 & 0.000 & 0.000 \\
\hline $\mathrm{m} 2: p$-value & 0.699 & 0.446 & 0.351 & 0.320 & 0.402 & 0.289 \\
\hline Hansen OID test, $p$-value & 0.615 & 0.602 & 0.633 & 0.296 & 0.576 & 0.634 \\
\hline Difference-in-Hansen test, $p$-value & 0.812 & 0.741 & 0.768 & 0.265 & 0.843 & 0.472 \\
\hline Comfac, $p$-value & 0.983 & 0.965 & 0.976 & 0.984 & 0.917 & 0.975 \\
\hline $\mathrm{Nb}$ instruments & 41 & 41 & 41 & 41 & 41 & 41 \\
\hline
\end{tabular}

Note: Absolute robust $t$ statistics in parentheses. Control variables are included in all the models but are not reported. Comfac is a minimum distance test of the non-linear common factor restrictions imposed in the restricted models. P-values are reported. Differencein-Hansen test reports the $p$-values based on the null hypothesis that the instruments in the levels equation are exogenous. The governance variables are reverted so that high values indicate a high level of bad governance. All the variables excepting the governance measures are expressed in natural logarithm form. $\mathrm{m} 1$ and $\mathrm{m} 2 p$-values refer to the Arellano and Bond (1991) test of autocorrelation of order 1 and 2 of residuals in first difference, respectively. The one-step system-GMM is retained to estimate the coefficients. The unit of analysis is the country and the unit of observation is the year. Remittances and remittances crossed with the governance variables are treated as predetermined and therefore instrumented by their lagged values. The log of the GDP per capita in the host countries and this variable crossed with the indicators of governance are added in the instrument matrix. Dependent variable: log of public health spending-to-GDP. ${ }^{*} p<0.10,{ }^{* *} p<0.05,{ }^{* * *} p<0.01$. 
Table A6: Governance quality, remittances and public education spending, Results using the principal component analysis of the governance indicators. (system-GMM estimator)

\begin{tabular}{|c|c|c|c|}
\hline & $(1)$ & $(2)$ & $(3)$ \\
\hline \multirow[t]{2}{*}{ Remittances } & 0.097 & 0.086 & 0.069 \\
\hline & $(1.47)$ & $(1.37)$ & $(1.55)$ \\
\hline \multirow[t]{2}{*}{ Remittances*Governance quality } & $-0.294^{* * *}$ & $-0.275^{* * *}$ & $-0.298^{* * *}$ \\
\hline & $(1.99)$ & $(1.99)$ & $(2.12)$ \\
\hline \multirow[t]{2}{*}{ Governance quality index (composite index) } & -0.547 & -0.560 & 0.204 \\
\hline & $(1.56)$ & $(1.53)$ & $(0.51)$ \\
\hline \multirow[t]{2}{*}{ Lag of the dependent variable } & $0.675^{* * *}$ & $0.670^{* * *}$ & $0.950^{* * * *}$ \\
\hline & $(3.81)$ & $(3.72)$ & $(93.79)$ \\
\hline Observations & 537 & 526 & 421 \\
\hline Countries & 80 & 78 & 75 \\
\hline $\mathrm{m} 1: p$-value & 0.000 & 0.001 & 0.016 \\
\hline $\mathrm{m} 2: p$-value & 0.807 & 0.760 & 0.448 \\
\hline Hansen OID test, $p$-value & 0.694 & 0.691 & 0.295 \\
\hline Difference-in-Hansen test, $p$-value & 0.705 & 0.485 & 0.248 \\
\hline Comfac test, $p$-value &.. &.. & 0.575 \\
\hline $\mathrm{Nb}$ instruments & 27 & 29 & 35 \\
\hline
\end{tabular}

Note: Absolute robust $t$ statistics in parentheses. Control variables are included in all the models but are not reported. The governance index is computed from a principal component analysis on the six dimensions of governance used before and is rescaled between 0 and 1 . All the variables excepting the governance measure are expressed in natural logarithm form. $\mathrm{m} 1$ and $\mathrm{m} 2 p$-values refer to the Arellano and Bond (1991) test of autocorrelation of order 1 and 2 of residuals in first difference, respectively. The one-step system-GMM is retained to estimate the coefficients. Difference-inHansen test reports the $p$-values based on the null hypothesis that the instruments in the levels equation are exogenous. Comfac is a minimum distance test of the non-linear common factor restrictions imposed in the restricted models. $P$-values are reported. The unit of analysis is the country and the unit of observation is the year. Remittances and remittances crossed with the governance variable are treated as predetermined and therefore instrumented by their lagged values (Column 1) and I augment the instrument matrix with the log of GDP per capita in the host countries and with this variable crossed with the governance index (Column 2). In column (3), I estimate the model by imposing and testing for the common factor representation. Dependent variable: $\log$ of public education spending-to-GDP. ${ }^{*} p<0.10,{ }^{* *} p<0.05,{ }^{* * *} p<0.01$. 
Table A7: Governance quality, remittances and public health spending, Results using the principal component analysis of the governance indicators (system-GMM estimator).

\begin{tabular}{|c|c|c|c|}
\hline & $(1)$ & $(2)$ & (3) \\
\hline Remittances & $\begin{array}{l}0.078 \\
(1.64)\end{array}$ & $\begin{array}{l}0.055 \\
(1.31)\end{array}$ & $\begin{array}{c}0.037^{* *} \\
(2.14)\end{array}$ \\
\hline Remittances*Governance quality & $\begin{array}{c}-0.271^{* *} \\
(2.47)\end{array}$ & $\begin{array}{c}-0.226^{* *} \\
(2.12)\end{array}$ & $\begin{array}{c}-0.162^{* *} \\
(2.49)\end{array}$ \\
\hline Governance quality index (composite index) & $\begin{array}{c}-0.368 \\
(1.45)\end{array}$ & $\begin{array}{r}-0.373 \\
(1.44)\end{array}$ & $\begin{array}{c}-1.450^{* *} \\
(2.18)\end{array}$ \\
\hline Lag dependent variable & $\begin{array}{c}0.745^{\text {**** }} \\
(8.19)\end{array}$ & $\begin{array}{c}0.756^{* * *} \\
(8.45)\end{array}$ & $\begin{array}{c}0.783^{* * * *} \\
(9.36)\end{array}$ \\
\hline Observations & 575 & 565 & 530 \\
\hline Countries & 86 & 83 & 81 \\
\hline $\mathrm{m} 1: p$-value & 0.000 & 0.000 & 0.000 \\
\hline $\mathrm{m} 2: p$-value & 0.239 & 0.241 & 0.315 \\
\hline Hansen OID test, $p$-value & 0.210 & 0.285 & 0.666 \\
\hline Difference-in-Hansen test, $p$-value & 0.043 & 0.056 & 0.522 \\
\hline Comfac test, $p$-value &.. &.. & 0.946 \\
\hline $\mathrm{Nb}$ instruments & 31 & 33 & 41 \\
\hline
\end{tabular}

$\mathrm{Nb}$ instruments

Note: Absolute robust $t$ statistics in parentheses. Control variables are included in all the models but are not reported. The governance quality index is computed from a principal component analysis on the six dimensions of governance used before and is rescaled between 0 and 1. All the variables excepting the governance measure are expressed in natural logarithm form. $\mathrm{m} 1$ and $\mathrm{m} 2 \mathrm{p}$-values refer to the Arellano and Bond (1991) test of autocorrelation of order 1 and 2 of residuals in first difference, respectively. The one-step system-GMM is retained to estimate the coefficients. Difference-in-Hansen test reports the $p$ values based on the null hypothesis that the instruments in the levels equation are exogenous. Comfac is a minimum distance test of the non-linear common factor restrictions imposed in the restricted models. $P$ values are reported. The unit of analysis is the country and the unit of observation is the year. Remittances and remittances crossed with the governance variable are treated as predetermined and therefore instrumented by their lagged values (Column 1) and I augment the instrument matrix with the log of GDP per capita in the host countries and with this variable crossed with the governance index (Column 2). In column (3), I estimate the model by imposing and testing for the common factor representation. Dependent variable: $\log$ of public health spending-to-GDP. ${ }^{*} p<0.10,{ }^{* *} p<0.05,{ }^{* * * *} p<0.01$. 


\section{Response to the Referee (Revision \#3)}

Again, I would sincerely like to thank the referee for the insightful comments provided in his latest report. The referee pointed out three main points and four brief comments in his report and globally, I totally agree with the referee on all these points. Following all the suggestions provided in the report, I have proceeded to the required revisions of the manuscript. Below are the descriptions of the changes made.

1. Following the referee's suggestion, I have replaced all the references to government vulnerability with the terms 'governance' or sometimes 'governance quality', 'good governance' or 'bad governance'. The expression 'governance vulnerability' has been therefore deleted and replaced in every part of the paper and in the Tables.

2. The limitations of the six dimensions of 'governance' have been now explicitly stated in the paper. I have proceeded in two steps. I have borrowed the new paragraph suggested by the referee in the report and I have added to this paragraph the previous footnote \#10. This new paragraph has been introduced in the body of the text (page \#10) just after the enumeration of the six indicators of governance. I' $m$ indebted to the referee with this new paragraph.

3. A discussion about the reverse causality problem between remittances and public social spending has been introduced in the text (page \#7). The paragraph also discusses how the GMM estimators, by using the lagged values of variables to instrument the contemporaneous values help deal with the reverse causation bias. The rationale behind is that it is difficult to assess that the contemporaneous levels of public social spending affect the lagged levels of remittance inflows. Finally, the augmented GMM estimator used in the paper which combines the 'ready made' instruments (the lagged values of variables in levels or/and in differences) and an 'external instrument' for remittances (the average real income per capita in the migrant host countries) could also reduce the bias due to the reverse causality.

\section{On the 'four new brief comments'}

4. The term 'rogue government' has been changed following the referee's suggestion. 
5. The beginning of footnote related to the A-H estimator (now the footnote \#3) has been revised by adding the paragraph edited by the referee. Again, I would like to thank the referee for having suggested me this paragraph.

6. Following the advice of the referee, in page \#12 and after, a discussion on the implications of the significance of the coefficient associated with the lagged dependent variables has been provided in the text. The main idea is that in a context of relatively strong inertia of the variables, the difference-GMM estimator is not useful for the identification of the parameters due to the fact that the lagged variables in levels used as instruments explain very little the instrumented variables in first differences. This is why the paper also resorts to the system-GMM method, which is more efficient in such a case.

7. Following the suggestion of the referee, the last paragraph of the conclusion has been removed. 